\title{
Ecological Tax: an Essential Weapon in Macro-Ecological Economics
}

\author{
Yifei Lei* \\ The University of Edinburgh, UK
}

Keywords: Ecological tax; Green dividend; Blue dividend.

\begin{abstract}
The 2008 economic crisis influences mainstream economics, people begin to reflect on the current economic development model. As an indispensable tool in ecological policy, ecological tax plays an essential role in macro-ecological economics. This paper focuses on the double dividend hypothesis of ecological tax. The study introduces the green dividend of ecological tax, and discusses the blue dividend of eco-tax. The last part is a critical reflection on green taxes.
\end{abstract}

\section{Introduction}

The 2008 economic crisis gave mainstream economics, which made rapid economic growth a primary policy goal, a big blow [1]. People begin to reflect on the current economic development model. According to ecological economists, the market is not efficient enough to allocate many scarce resources, and the overuse of public goods can lead to the "tragedy of the Commons"[2]. Policy intervention is necessary for the adequate supply of these non-market goods and services. As an indispensable tool in ecological policy, ecological tax (green tax) plays an essential role in macro-ecological economics [3]. The OECD first emphasized the relevance of environment and taxation in 1992 and proposed Green Reforms in 1996, triggering the Green revolution in taxation in western Countries [4]. O'Riordan [5] defines ecological taxes as taxes levied on environmentally harmful activities and aims to promote environmentally friendly activities through economic incentives. In other words, the ecological taxes are to internalize the social costs of ecological destruction into production costs and market prices and then allocate ecological resources through the market [6]. There are various types of eco-taxes, such as the carbon tax, which is a tax on carbon emissions from fossil fuels [7]. Sweden considered as the most prosperous country in using carbon taxes. Since the introduction of the carbon tax in the early 1990s, Sweden's carbon emissions have fallen below the level required by the Kyoto Protocol [8].

The importance of ecological tax in ecological macroeconomics is reflected in the externality theory and double dividend hypothesis [9]. Pigou's theory of "environmental externality" is the original theoretical source of ecological tax [10]. Environmental externalities are the effects that people have on the environment when they engage in certain activities, but the environmental costs cannot be counted into the costs of products and transactions; Ecological taxes can correct the externalities of ecological problems through cost transfer [11]. Hakonsen well explained the "double dividend" hypothesis [10], indicating that ecological tax can achieve the goal of "double 
dividend": improve the environment (green dividend) and increase efficiency by reducing market distortions (blue dividend).

Based on the above background, this study focuses on the double dividend hypothesis of ecological tax. The structure of this study is shown in figure 1. The second section introduces the green dividend of ecological tax. In section 3, the study discusses the blue dividend of eco-tax. Section 4 is a critical reflection on green taxes before the conclusion in section 5 . The structure of this study is shown in figure 1 .

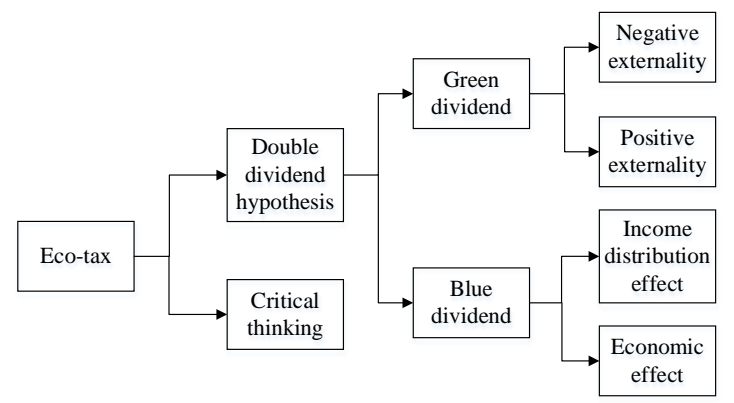

Figure 1: The structure of the study

\section{The Green Dividend of Ecological Tax}

The key to the double dividend is "environmental dividend". The main goal of ecological taxes is to improve the ecological environment; that is, ecological tax can bring eco-efficiency [12]. Externality theory is an important theoretical basis for carbon taxes to effectively control greenhouse gas emissions [13]. Ecological green dividend tax mainly reflected in the correction of negative externalities and positive externalities of the environment.

\subsection{Correction of Negative Externalities of Ecological Environment}

The non-competitive and non-exclusive public goods enable some people who are reluctant to pay for such goods to enjoy the same amount of ecosystem services, resulting in the free-rider problem [14]. Excessive use of the ecological resources by the public will cause damage to the ecological resources and produce negative externalities to the ecology [11]. The correction process of eco-tax to negative externalities is shown in figure 2.

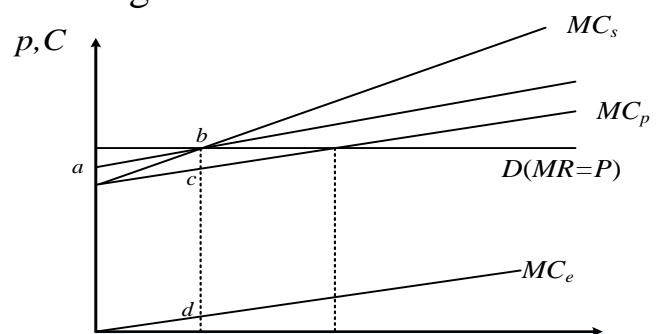

Figure 2: Correction of negative externalities by ecological tax

The $\mathrm{X}$-axis represents the degree of resource use, the $\mathrm{Y}$-axis represents the cost of resource use, the represents the marginal external cost curve, the represents the marginal private cost curve, the represents the marginal social cost curve, and the curve D represents the marginal benefit per unit of resource use.

As rational individuals, they will use resources to reach a point where they maximize their profits. that is, $\mathrm{MC}_{\mathrm{P}}=\mathrm{MR}$. When considering resource externalities, the best point for the whole society is $\mathrm{X}_{\mathrm{S}}$. That is, $\mathrm{MC}_{\mathrm{s}}=\mathrm{MR}$. It is important to note that resources can be overused by individuals if $\mathrm{X}_{\mathrm{S}}<\mathrm{X}_{P}$. If individuals are levied an ecological tax $\mathrm{d}$ - , then will shift to ab, where 
$\mathrm{bc}=\mathrm{dx}_{\mathrm{s}}$. As far as rational individuals are concerned, the point of individual profit maximization will fall to a point $x_{s}$, which coincides with the point of social profit maximization. Therefore, eco-taxes can solve the problem of negative externalities of individuals' excessive use of resources.

The implementation of ecological tax increases the cost of producers through cost transfer, thereby reducing the production of polluting products by enterprises and the purchase of products by consumers [15]. It successfully corrects the negative externalities of the environment, reduces ecological pollution and improves ecological benefits [15]. The Netherlands imposes a waste disposal tax on companies that discharge industrial waste. The waste disposal tax limits the further expansion of highly polluting enterprises by raising the prices of production factors, reduces consumer consumption of highly polluting products, and reduces waste emissions [16].

\subsection{Correction of Positive Externalities of Ecological Environment}

The government can encourage the implementation of ecological projects to generate positive externalities of ecosystem services through transfer payments. The process is presented in figure 3 .

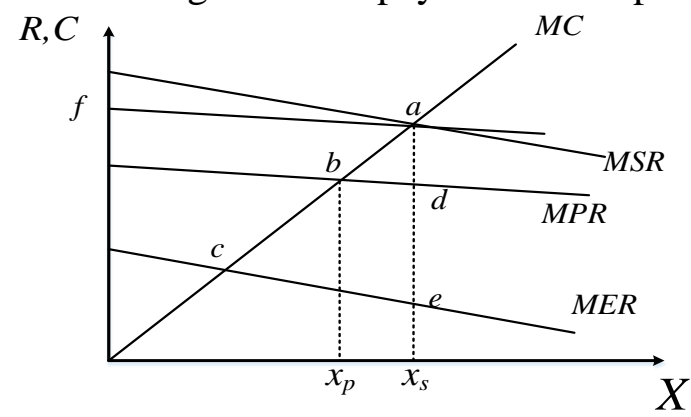

Figure 3: Correction of positive externalities by ecological tax

The x-axis represents the number of ecological projects, the $y$-axis represents the marginal cost of ecological projects, MER represents the marginal external income curve, MPR represents the marginal individual income curve, MSR represents the marginal social income curve; MC represents the marginal cost of ecological projects.

As rational individuals, they choose to maximize the profit when the number of ecological projects reaches a point $X_{P}$, where MPR $=$ MC. It's important to note that $X_{S}>X_{P}$ means that the ecological project number is smaller than the optimal state of society. If a tax preference is given to the individual $\mathrm{ex}_{s}$, the MPR will shift to the position of the fa, where $\mathrm{ad}=\mathrm{ex}_{s}$. As far as rational individuals are concerned, the point of individual profit maximization will fall to a point $\mathrm{ex}_{s}$, which is consistent with the point of maximizing social profits. Therefore, eco-tax compensation or preference can correct the externalities of insufficient implementation of private sector ecological projects.

The ecological fiscal transfer (EFT), which originated in Parana, Brazil, is an important part of government fiscal transfer payments. It distributes taxes among different levels of government according to ecological criteria. The EFT provides financial support to local governments to ensure that they perform public functions [17]. The EFT has become the vital driving force for the establishment of new protected areas and improved environmental management, especially in terms of biodiversity in protected areas. Data from Parana state show that the state's total protected area has increased by $164.5 \%$ since the introduction of EFT in 1991[18]. 


\section{The Blue Dividend of Ecological Tax}

Ecological tax can be used to reduce the distortion of the current tax system on capital and labour, thereby driving economic growth, and increasing more social employment. Income distribution and economic growth are the main research directions of macro-ecological economics [19]. Therefore, the study of the blue dividend in this paper mainly focuses on income distribution effect and economic benefits.

\subsection{The Effect of Income Distribution}

Tax reallocation is an important tool to achieve equitable income distribution. Eco-taxes can regulate personal wealth and gradually narrow the gap between the rich and the poor [20]. The uneven income distribution will affect ecological protection in many ways. The level of income affects how much people value ecological protection. When people's survival problems cannot be solved, there is no time for them to consider the need for eco-protection, or they may even sacrifice the environment for personal interests [21]. If environmental externalities are part of the economy, a massive wealth gap between regions or countries will lead to the import of resources from developed countries and the export of pollution and emissions. The resource use and pollution emissions will lead to the problem of cross-regional pollution, which will result in ecological distribution conflicts and even environmental justice movements [22]. At the same time, intergenerational income inequality will cause the current generation to consume the resources of future generations in advance, resulting in overexploitation [23]. Therefore, ecological protection and income distribution equity are complementary to each other in macro-ecological economics.

The debate over the effects of income distribution has focused on the regressiveness of environmental taxes. Taxpayers are heterogeneous, and in any country, the rich are always in the minority but the poor are always in the majority. Taxation at the same tax rate has a more significant negative impact on the welfare of low-income families than that of the rich [24]. In France, for example, the negative impact of energy taxes on low-income households is more than three times that of high-income households, which runs counter to the country's requirements for environmental justice [25]. A study by West and Williams [26] of the gasoline tax shows that whether the tax is regressive or progressive depends on whether and how the tax return. They concluded that if the gasoline tax returned as a lump-sum tax, it would be progressive. Hagopian argued that green taxes play a significant role in income distribution when they returned through payroll or income taxes, and that the progressive nature of the entire tax system can be enhanced through green tax reform [27]. While the regressive nature of eco-taxes is politically unacceptable, there is also evidence showing that several factors can mitigate or even eliminate the regressive nature of eco-taxes [6]. Therefore, this point should be taken into account when formulating the tax reform plan, and generally speaking, environmental tax plays a vital role in income distribution and environmental justice.

\subsection{The Effect of Economic Growth}

Many arguments have been made about the relationship between economic growth and the environment. One of these questions is the impact of ecological policy on economic growth. In the short term, ecological policies that improve ecological quality can have a negative impact on growth due to the additional production costs [28]. For example, the industrial structure of China's Shandong Province dominated by heavy industry, and economic development relies heavily on resources and energy, coal consumption in heavy industry accounts for $92.7 \%$ of the province's coal consumption in 2011[29]. As shown in figure 4, the increase in carbon taxes has led to an increase 
in the tax burden on some industries such as steel industry, and the transfer of external costs has led to an increase in production costs. After the introduction of the carbon tax, the tax burden cannot be transferred in the short term if the market price remains unchanged, which will cause a decline in industrial profits and affect the competitiveness of industries [29]. This trend will have a negative effect on the economy of Shandong Province.

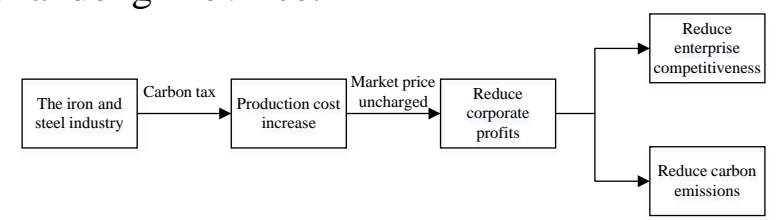

Figure 4: The impact of the carbon tax on the steel industry

In the long run, eco-taxes can boost economic growth by affecting investment and productivity. Firstly, the levy of eco-tax will change the investment direction. Due to the increase in cost, investment in highly polluting industries will decrease. On the contrary, the rise of green investment will provide financial support for the ecological industry, thereby driving the transformation of the model of economic growth [30]. On the other hand, the endogenous growth model is used to analyze the impact of eco-tax on the long-term growth rate. In the two-sector endogenous growth models, labour-leisure Choices play a role in the eco-tax effect. In response to environmental growth, companies have to reduce emissions, which reduce final output. This reduction has also led families to substitute educational time for leisure time, which ultimately increases the long-term growth rates [31]. Besides, Berliant modified Futagam's model to analyze the impact of fiscal policy on long-term growth [32]. He also proved that pollution tax has a positive effect on economic growth because higher pollution tax revenue will increase the stock of public capital and thus will have a positive effect on growth.

Although eco-taxes may have a negative impact on economic growth in the short term, Loganathan and Nanthakumar argue that environmental policies promote innovation and that the long-term benefits outweigh the short-term economic losses [33]. They call this phenomenon "innovation compensation". At the same time, Oueslati shows that by integrating the endogenous growth model and taking environmental quality as one of the production factors, the implementation of green tax can not only improve the environmental quality but also improve the total factor productivity of the economy [34].

\section{Critical Thinking on Eco-Taxes}

In the research on the double dividend of ecological tax, there are few objections to the green dividend. Nevertheless, in the blue dividend, scholars have different views. It has been argued that ecological taxation can improve ecological quality and achieve less distortion of the taxation system, which may lead to a double dividend [35]. However, a large number of studies have refuted the hypothesis of double dividend. The double dividend hypothesis is not existed when the economy consists of a productive sector or only one factor of production [36]. However, when there is more than one factor of production and more than one consumer group, the dividend can be doubled. For example, Kilimani took Uganda as an example to analyze the influence of water tax on developing countries [37]. The study found that doubling can only occur under certain conditions, so policymakers need to have a deeper understanding of specific economies and design policies carefully.

For the issue of double dividend, different researchers may come to different conclusions, and even the same researcher may reach different conclusions in different studies. Whether green tax reform can produce double dividend is not a theoretical question, but an empirical question. The 
research on double dividend and green tax may never perfectly explained from the theoretical model, but it should be based on the practical background of various countries.

\section{Conclusion}

This study discussed the role of green tax and the possibility of a double dividend following the eco-tax reform. The double dividend hypothesis implies not only the ecological benefits of improving the ecological environment but also the increased benefits of reducing tax distortions such as economic growth and equitable distribution of income. Although many scholars still dispute the existence of the second dividend, for example, in the short term, the ecological tax will have a negative impact on economic growth due to the increase in production costs. Nevertheless, by increasing this effect by eco-tax reform, sustainable growth can be achieved. These results show that eco-tax and eco-tax reform can bring economic and environmental benefits in the long term and ultimately achieve goals for sustainable development. However, reform policies need to be carefully developed in order to minimize the negative impact of reform on specific countries and governments.

\section{References}

[1] Botlhale, E. Restoring Fiscal Balances Post the Global Economic Crisis in Botswana. International Journal of Public Administration, 40(8), 706-716, 2017.

[2] David, Z. Desalination and the Commons: Tragedy or Triumph? International Journal of Water Resources Development, 33 (6), 890-906, 2017.

[3] Daly, H.E\& Farley, J. C. Ecological Economics: Principles and Applications 2nd ed., Washington, DC: Island Press, 2010.

[4] Barde, J.-P. Green Tax Reforms in OECD Countries: An Overview. Journal of Business Administration and Policy Analysis, 681-714, 1999.

[5] O'Riordan, T. Ecotaxation, London: Earthscan, 1997.

[6] de Miguel, C. \& Manzano, B. (2011) Gradual Green Tax Reforms. Energy Economics, 33(S1), pp.S50-S58.

[7] Metcalf, G.E Paying for Pollution: Why A Carbon Tax Is Good for America, New York, NY: Oxford University Press, 2019.

[8] Jagers, S.C. \& Hammar, H. Environmental Taxation for Good and for Bad: the Efficiency and Legitimacy of Sweden's Carbon Tax. Environmental Politics, 18(2), 218-237, 2009.

[9] Fernández, E., Pérez, R. \& Ruiz, J. Optimal Green Tax Reforms Yielding Double Dividend. Energy Policy, 39(7), 4253-4263, 2011.

[10] Hakonsen, L. A Note on Green Taxes and Double Dividends. International Tax and Public Finance, 8(1), 75-80, 2001.

[11] Gorelkina, O the Expected Externality Mechanism in A Level- K Environment. International Journal of Game Theory, 47(1), 103-131, 2018.

[12] Kilimani, N. Water Taxation and the Double Dividend Hypothesis. IDEAS Working Paper Series from RePEc, pp.IDEAS Working Paper Series from RePEc, 2014.

[13] Nerudova, D. \& Dobranschi, M. (20150 Double Dividend Hypothesis: Can It Be Validated By Carbon Taxation Swap With Payroll Taxes? Inzineriné Ekonomika, 26(1), pp.23-32.

[14] Abásolo, I. \& Tsuchiya, A. Blood Donation as a Public Good: An Empirical Investigation of the Free Rider Problem. The European Journal of Health Economics, 15(3), pp.313-321.

[15] Glomm, G., Kawaguchi, D. \& Sepulveda, F. Green Taxes and Double Dividends in a Dynamic Economy, Journal of Policy Modeling, 30(1), 19-32.

[16] Heijnen, P. \& Elhorst, J. The Diffusion of Local Differentiated Waste Disposal Taxes in the Netherlands. De Economist, 166(2), 239-258.

[17] Borie, M. et al. Exploring the Contribution of Fiscal Transfers to Protected Area Policy. Ecology and Society, 19(1), 1-9.

[18] Sauquet, A., Marchand, S. \& Féres, J.G. Protected Areas, Local Governments, and Strategic Interactions: The Case of the ICMS-Ecológico in the Brazilian State of Paraná. Ecological Economics, 107(C), 249-258.

[19] Ekins, P. \& Speck, S. Environmental Tax Reform (ETR): A Policy for Green Growth, Oxford: Oxford University Press. 
[20] Artem V. Fiscal Policy Reaction Function and Sustainability of Fiscal Policy in Ukraine. Visnyk of the National Bank of Ukraine, (240), 22-35.

[21] Verbeke, T. \& De Clercq, M. The income-environment relationship: Evidence from a binary response model. Ecological Economics, 59(4), 419-428.

[22] Martínez A. The Environmentalism of the Poor: A Study of Ecological Conflicts and Valuation, Northhampton, MA: Edward Elgar Pub.

[23] Anon Intergenerational Earnings Mobility, Inequality, and Growth, Cambridge, Mass: National Bureau of Economic Research.

[24] Nichols, D.R., Plummer, E. \& Wempe, W.F. Equitable Taxation and the Provision of Health Insurance Subsidies. Business and Society Review, 116(4), 435-466.

[25] Roemer, John E. et al., 2003. To What Extent so Fiscal Regimes Equalize Opportunities for Income Acquisition Among Citizens? The Journal of Public Economics, 87(3 4), 539.

[26] West, S.E. \& Williams, R.C. (2004) Estimates from a consumer demand system: implications for the incidence of environmental taxes. Journal of Environmental Economics and Management, 47(3), pp.535-558.

[27] Hagopian, K. The Inequity of the Progressive Income Tax. Policy Review, (166), p.3.

[28] Loganathan, N., Shahbaz, M. \& Taha, R. (2014) The Link between Green Taxation and Economic Growth on CO2 Emissions: Fresh Evidence from Malaysia. Renewable and Sustainable Energy Reviews, 38, 1083-1091.

[29] Ren, L.J. \& Wang, W.J. Analysis of Existing Problems and Carbon Emission Reduction in Shandong's Iron and Steel Industry. Energy Procedia, 5, 1636-1641.

[30]Xuexian Gao \& Haidong Zheng Environmental Concerns, Environmental Policy and Green Investment. International Journal of Environmental Research and Public Health, 14(12), 1570.

[31] Hettich, F. Growth Effects of A Revenue-Neutral Environmental Tax Reform. Journal of Economics, 67(3), 287-316.

[32] Berliant, M., Peng, S.-K. \& Wang, P., 2014. Taxing Pollution: Agglomeration and Welfare Consequences. Economic Theory, 55(3), 665-704.

[33] Loganathan, N., Shahbaz, M. \& Taha, R. The Link between Green Taxation and Economic Growth on CO.sub.2 Emissions: Fresh Evidence from Malaysia. Renewable and Sustainable Energy Reviews, 38, 1083.

[34] Oueslati, W. Environmental Tax Reform: Short-term Versus Long-Term Macroeconomic Effects. Journal of Macroeconomics, 40(C), 190-201.

[35] Goulder, L. Environmental Taxation and the Double Dividend: A Reader's Guide. International Tax and Public Finance, 2(2), 157-183.

[36] Bosello, F., Carraro, C. \& Galeotti, M. The Double Dividend Issue: Modeling Strategies and Empirical Findings. Environment and Development Economics, 6, 9-45.

[37] Kilimani, N., Heerden, J.van \& Bohlmann, H. Water Taxation and the Double Dividend Hypothesis. Water Resources and Economics, 10(C), 68-91. 